\title{
Anti-inflammatory effects of tectroside on UVB-induced HaCaT cells
}

\author{
SUNG-BAE KIM $^{1 *}$, OK-HWA KANG ${ }^{1}$, DAE-KI JOUNG ${ }^{1 *}$, SU-HYUN MUN ${ }^{1}$, YUN-SOO SEO ${ }^{1}$, \\ MI-RAN CHA ${ }^{2}$, SHI-YONG RYU ${ }^{2}$, DONG-WON SHIN ${ }^{3}$ and DONG-YEUL KWON ${ }^{1}$ \\ ${ }^{1}$ College of Pharmacy and Wonkwang-Oriental Medicines Research Institute, Institute of Biotechnology, \\ Wonkwang University, Jeonbuk 570-749; ${ }^{2}$ Korea Research Institute of Chemical Technology, Daejeon 305-600; \\ ${ }^{3}$ Department of Oriental Medicine Resources, Sunchon National University, Jeonnam 540-742, Republic of Korea
}

Received January 2, 2013; Accepted March 21, 2013

DOI: $10.3892 /$ ijmm.2013.1343

\begin{abstract}
Ultraviolet B (UVB) irradiation causes skin damage and inflammation by inducing the secretion of various cytokines, which are immune regulators produced by cells. To prevent skin inflammation, keratinocytes that have been irreversibly damaged by UVB must be eliminated through apoptosis. Ixeris dentata (I.dentata) (family Asteraceae) is a perennial medicinal herb indigenous to Korea. It is used in Korea, China and Japan to treat indigestion, pneumonia, diabetes, hepatitis, contusions and tumors. Guaiane-type sesquiterpene lactones were isolated from the whole extract of I. dentata. This led to the isolation of the anti-inflammatory sesquiterpene lactone compound tectroside (TES), which was tested on a human keratinocyte cell line. To determine the anti-inflammatory effects of TES, we examined its influence on UVB-induced pro-inflammatory cytokine production in human keratinocytes ( $\mathrm{HaCaT}$ cells) by observing these cells in the presence or absence of TES. In the present study, pro-inflammatory cytokine production was determined by performing enzyme-linked immunosorbent assay, reverse transcription-polymerase chain reaction and western blot analysis to evaluate the activation of mitogen-activated protein kinases (MAPKs). TES inhibited UVB-induced production of the pro-inflammatory cytokines interleukin (IL)-6 and IL-8 in a dose-dependent manner. In addition, TES inhibited the expression of cyclooxygenase (COX)-2 and the phosphorylation of c-Jun NH2-terminal kinase (JNK) and extracellular signalregulated kinase (ERK) MAPKs, suggesting that it inhibits the secretion of the pro-inflammatory cytokines IL-6 and IL-8 and COX-2 expression by blocking MAPK phosphorylation. These results suggest that TES can potentially protect against UVB-induced skin inflammation.
\end{abstract}

Correspondence to: Professor Dong-Yeul Kwon, College of Pharmacy and Wonkwang-Oriental Medicines Research Institute, Institute of Biotechnology, Wonkwang University, 344-2 Shinyongdong, Iksan, Jeonbuk 570-749, Republic of Korea

E-mail: sssimi@wku.ac.kr

${ }^{*}$ Contributed equally

Key words: Ixeris dentata, tectroside, ultraviolet $\mathrm{B}$, human keratinocyte

\section{Introduction}

The skin is the largest organ of the body and its function in the immune system has attracted the attention of both immunologists and dermatopathologists $(1,2)$. Ultraviolet (UV) radiation is the major environmental cause of skin damage $(3,4)$.

UVA $(320.400 \mathrm{~nm})$ and UVB $(280.320 \mathrm{~nm})$ radiations reach the earth's surface in amounts sufficient to have important biological consequences for the skin (5). UVB, in particular, has a wide spectrum of biological effects on the skin, and acute exposure causes a variety of adverse skin reactions, including erythema, edema, sunburn, hyperplasia, inflammation and immunosuppression (6). Furthermore, chronic UVB exposure leads to skin carcinogenesis and premature skin aging $(6,7)$.

In addition, exposure of cells to UVB radiation results in the loss of keratinocyte viability, an increase in membrane blebbing (8), cytoskeletal molecular changes (9-12) and apoptosis $(13,14)$. The whole plant of Ixeris dentata (I. dentata), a typical Oriental herb, has been used for the treatment of indigestion, pneumonia, hepatitis, contusions and tumors $(15,16)$; it is also used in folk medicine in Korea for the treatment of inflammatory diseases.

Recent pharmacological studies of I. dentata showed that water or organic solvent extracts of whole herbal medicine lower lipid concentrations and act as an antioxidant (17), antiallergic (18), monamine oxidase (19), anti-inflammatory $(20,21)$ antimutagenic and anticancer (22) activity. Although crude extracts of a single herbal medicine or herbal formula can exhibit striking biological effects, their mechanisms cannot be fully elucidated as they can contain innumerable compounds (23).

Guaiane-type sesquiterpene lactones were isolated from the whole extract of I. dentata. Subsequently, the effects of tectroside (TES) isolated from I. dentata on UVB-induced pro-inflammatory mediators were evaluated by inhibiting mitogen-activated protein kinases (MAPKs) in a human keratinocyte cell line, HaCaT.

The effect on skin inflammation has yet to be reported; therefore, as part of our ongoing screening program to evaluate anti-inflammatory potential of natural compounds, we investigated the in vitro anti-inflammatory activity of TES isolated from I. dentata. 


\section{Materials and methods}

Plant material. Whole plants of I. dentata were collected in May 2006 from the herbarium at the Korea Research Institute of Chemical Technology (KRICT) and were authenticated by Dr Young Sup Kim. A voucher specimen (KR0472) was deposited at the herbarium at KRICT (24).

Extraction and isolation. The air-dried whole plants $(6 \mathrm{~kg})$ of I. dentata were soaked in methanol $(\mathrm{MeOH})(2 \times 40$ liters $)$ at room temperature for 7 days. The $\mathrm{MeOH}$ extract was filtered and evaporated to dryness under reduced pressure. The concentrated extract $(840 \mathrm{~g})$ was suspended in 20 liters of water and then extracted successively with an equal volume of dichloromethane (MC), ethyl acetate (EtOAc), and n-butanol (n-BuOH), which yielded $160 \mathrm{~g}$ of the MC fraction, $15 \mathrm{~g}$ of the EtOAc fraction, and $60 \mathrm{~g}$ of the $\mathrm{n}-\mathrm{BuOH}$ fraction, respectively (24). The detailed purification procedures for TES from the fraction are shown in Fig. 1.

Reagents. RPMI-1640, penicillin, and streptomycin were obtained from HyClone Laboratories, Inc. (Logan, UT, USA). Bovine serum albumin and 3-(4,5-dimethylthiazol-2-yl)5-(3-carboxymethoxyphenyl)-2-(4-sulfophenyl)-2H-tetrazolium (MTS) were purchased from Sigma-Aldrich (St. Louis, MO, USA). Antibodies for extracellular signal-regulated kinase (ERK)1/2, phosphorylated ERK1/2, c-Jun NH2-terminal kinase (JNK), phosphorylated JNK, and $\beta$-actin, and peroxidaseconjugated secondary antibodies were purchased from Santa Cruz Biotechnology, Inc. (Santa Cruz, CA, USA). Antibodies for human interleukin (IL)-6 and IL-8 and biotinylated antibodies for human IL-6 and IL-8 were purchased from BD Biosciences (San Jose, CA, USA). The RNeasy Mini Kit and QuantiTect Reverse Transcription kit were purchased from Qiagen (Hilden, Germany). IL-6, IL-8, cyclooxygenase (COX)-2, and $\beta$-actin oligonucleotide primers were purchased from Bioneer Corp. (Daejeon, Korea).

Cell culture. HaCaT cells were grown in RPMI-1640 medium containing 5\% fetal bovine serum (FBS) and $100 \mathrm{U} / \mathrm{ml}$ penicillin/streptomycin sulfate. The cells were incubated in a humidified $5 \% \mathrm{CO}_{2}$ atmosphere at $37^{\circ} \mathrm{C}$. To stimulate the cells, the medium was replaced with fresh RPMI-1640 medium, and exposed to UVB in the presence or absence of TES for the indicated periods.

UVB source. UVB irradiation was delivered by a closely spaced array of 5 sunlamps (G9T5E lamps; Sankyo Denki Co., Hiratsuka, Japan). The distance between the sunlamps and the surface of the cell cultures was fixed at $7.5 \mathrm{~cm}$, and the distance between the sunlamps and the surface of the cage was fixed at $30 \mathrm{~cm}$. The energy output of the UVB $(290-320 \mathrm{~nm})$ lamps was measured using a UV radiometer (UVX; UVP Inc., Upland, CA, USA).

Cell viability assay. Cell viability was determined by the MTS assay. $\mathrm{HaCaT}$ cells were plated at a density of $3 \times 10^{4}$ cells/well in 96-well plates (Nunc, Copenhagen, Denmark). Each experiment included a non-treated group as the control. To determine the non-toxic concentration for the cells, TES $(2.5,5,10$ and

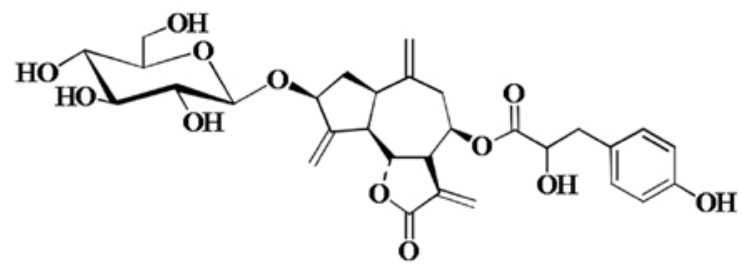

Figure 1. The chemical structure of tectroside.

$20 \mu \mathrm{M})$ was added to each well. The plates were incubated for $24 \mathrm{~h}$ at $37^{\circ} \mathrm{C}$ under $5 \% \mathrm{CO}_{2}$. The MTS solution $(5 \mathrm{mg} / \mathrm{ml})$ was added to each well, and the cells were cultured for another $2 \mathrm{~h}$, after which the optical density was read at $490 \mathrm{~nm}$. Cytotoxicity was then calculated using the formula: 1 - (mean absorbance value of treated cells/mean absorbance value of untreated cells).

Enzyme-linked immunosorbent assay (ELISA). Cells were seeded at a density of $3 \times 10^{4}$ cells/well in 48 -well tissue culture plates and pretreated with 2 concentrations of TES (5 and $10 \mu \mathrm{M})$ for $24 \mathrm{~h}$ prior to UVB $\left(100 \mathrm{~mJ} / \mathrm{cm}^{2}\right)$ stimulation. ELISA plates (Nunc) were coated overnight at $4^{\circ} \mathrm{C}$ with anti-human IL-6 and IL-8 antibodies diluted in coating buffer (0.1 M carbonate, $\mathrm{pH}$ 9.5), and then washed 3 times with phosphate-buffered saline (PBS) containing 0.05\% Tween-20. Nonspecific protein-binding sites were blocked with an assay diluent (PBS containing 10\% FBS, pH 7.0) for at least $1 \mathrm{~h}$. Immediately, each sample or the IL-6 or IL-8 standard was added to the wells. Following incubation for $2 \mathrm{~h}$, a working detector was added and incubated for $1 \mathrm{~h}$. Accordingly, the substrate solution (tetramethylbenzidine) was added to the wells and incubated for $30 \mathrm{~min}$ in the dark before the reaction was stopped with $2 \mathrm{~N} \mathrm{H}_{3} \mathrm{PO}_{4}$. Absorbance was read at $450 \mathrm{~nm}$. All subsequent steps were performed at room temperature, and all standards and samples were assayed in duplicate.

Western blot analysis. Protein expression was assessed by western blot analysis according to standard procedures. The $\mathrm{HaCaT}$ cells were cultured in 60-mm-diameter culture dishes ( $4 \times 10^{6}$ cells/well) and pretreated with 2 concentrations of TES (5 and $10 \mu \mathrm{M})$. After $30 \mathrm{~min}, 2$ or $24 \mathrm{~h}$, the cells were UVB-irradiated $\left(100 \mathrm{~mJ} / \mathrm{cm}^{2}\right)$ and then incubated at $37^{\circ} \mathrm{C}$. Following incubation, the cells were washed twice in ice-cold PBS (pH 7.4). The cell pellets were resuspended in lysis buffer on ice for $20 \mathrm{~min}$, and the cell debris was removed by centrifugation. Protein concentrations were determined using a Bio-Rad protein assay reagent (Bio-Rad Laboratories, Hercules, CA, USA) according to the manufacturer's instructions. Equal amounts of protein $(20 \mu \mathrm{g})$ were subjected to sodium dodecyl sulfate-polyacrylamide gel electrophoresis and then transferred onto a polyvinylidene membrane (Millipore, Bedford, MA, USA).

The membrane was blocked with 5\% nonfat milk in Trisbuffered saline with Tween-20 buffer $(150 \mathrm{mM} \mathrm{NaCl}, 20 \mathrm{mM}$ Tris- $\mathrm{HCl}$, and $0.05 \%$ Tween-20, $\mathrm{pH}$ 7.4). After blocking, the membrane was incubated with primary antibodies for $18 \mathrm{~h}$, washed with Tris-buffered saline with Tween-20, and incubated again with anti-mouse or anti-rabbit immunoglobulin $\mathrm{G}$ horseradish peroxidase-conjugated secondary antibodies. Immunoreactivity was detected using enhanced chemiluminescence (Amersham, Milan, Italy). 


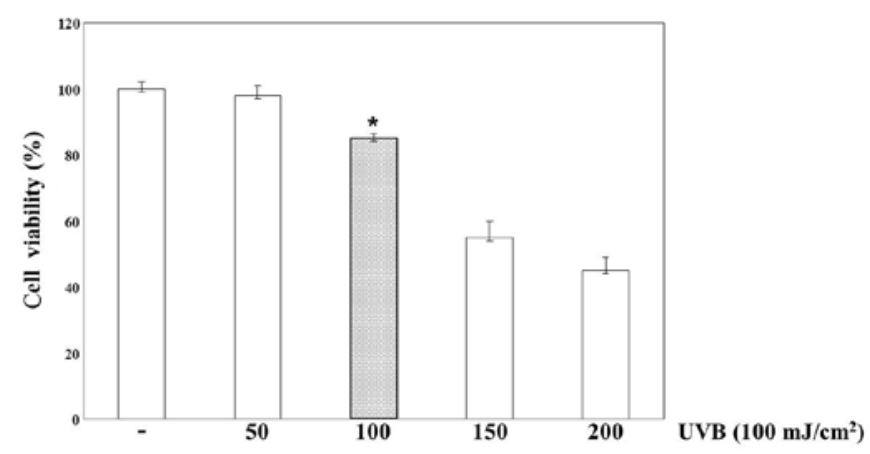

Figure 2. Viability of HaCaT cells under various conditions. HaCaT cells were used for the MTS assay at $24 \mathrm{~h}$ after 50,100 , or $150 \mathrm{~mJ} / \mathrm{cm}^{2} \mathrm{UVB}$ irradiation and comparison of the viability of irradiated cells with that of the non-irradiated control. Data are the means \pm SD values from triplicate experiments. ${ }^{*} \mathrm{P}<0.05$.

RNA extraction and reverse transcription-polymerase chain reaction $(R T-P C R)$. HaCaT cells were cultured in 6-well tissue culture plates $\left(8 \times 10^{5}\right.$ cells/well) and pretreated with 2 concentrations of TES ( 5 and $10 \mu \mathrm{M}$ ). After $30 \mathrm{~min}$, the cells were irradiated with UVB $\left(100 \mathrm{~mJ} / \mathrm{cm}^{2}\right)$ and incubated at $37^{\circ} \mathrm{C}$. Following incubation, the cells were washed twice in ice-cold PBS (pH 7.4). Total cellular RNA was isolated using the RNA Mini Kit (Qiagen), and $1 \mu \mathrm{g}$ of total RNA was reverse transcribed using the QuantiTect Reverse Transcription Kit (Qiagen) according to the manufacturer's instructions. The total RNA $(2 \mu \mathrm{g})$ was converted to cDNA by treating it with
200 units of reverse transcriptase and $500 \mathrm{ng}$ of oligo(dT) primer in $50 \mathrm{mM}$ Tris- $\mathrm{HCl}(\mathrm{pH} 8.3), 75 \mathrm{mM} \mathrm{KCl,} 3 \mathrm{mM}$ $\mathrm{MgCl}_{2}, 10 \mathrm{mM}$ dithiothreitol, and $1 \mathrm{mM}$ deoxynucleotide triphosphates at $42^{\circ} \mathrm{C}$ for $1 \mathrm{~h}$. The reaction was stopped by heating at $70^{\circ} \mathrm{C}$ for $15 \mathrm{~min}$, and the cDNA mixture $(3 \mu \mathrm{l})$ was used for enzymatic amplification. PCR was performed using $50 \mathrm{mM} \mathrm{KCl}, 10 \mathrm{mM}$ Tris- $\mathrm{HCl}$ (pH 8.3), $1.5 \mathrm{mM} \mathrm{MgCl}_{2}$, $0.2 \mathrm{mM}$ deoxynucleotide triphosphates, 2.5 units of TaqDNA polymerase, and $0.1 \mu \mathrm{M}$ each of the IL-6, IL-8, COX-2, or $\beta$-actin primers.

Statistical analysis. Statistical analysis was performed using one-way analysis of variance (ANOVA) or Student's t-test for single comparisons. All data are presented as the means \pm standard error (SE), and the number of individual experiments conducted is mentioned in each figure legend.

\section{Results}

Cell viability of UVB-irradiated HaCaT cells. The effect of TES on cell viability following UVB irradiation was tested on HaCaT cells. Cell viability was evaluated using an MTS assay (Fig. 2). When the cultures were incubated after UVB irradiation, UVB-induced toxicity increased compared to that in non-irradiated cells. Cell viability declined, depending on the dose of UVB irradiation, and sharply reduced at $24 \mathrm{~h}$ after UVB irradiation of $150 \mathrm{~mJ} / \mathrm{cm}^{2}$. Accordingly, we selected an exposure dose of $100 \mathrm{~mJ} / \mathrm{cm}^{2}$ for studying cellular toxicity in $\mathrm{HaCaT}$ cells treated with TES $24 \mathrm{~h}$ after UVB irradiation (Fig. 3).
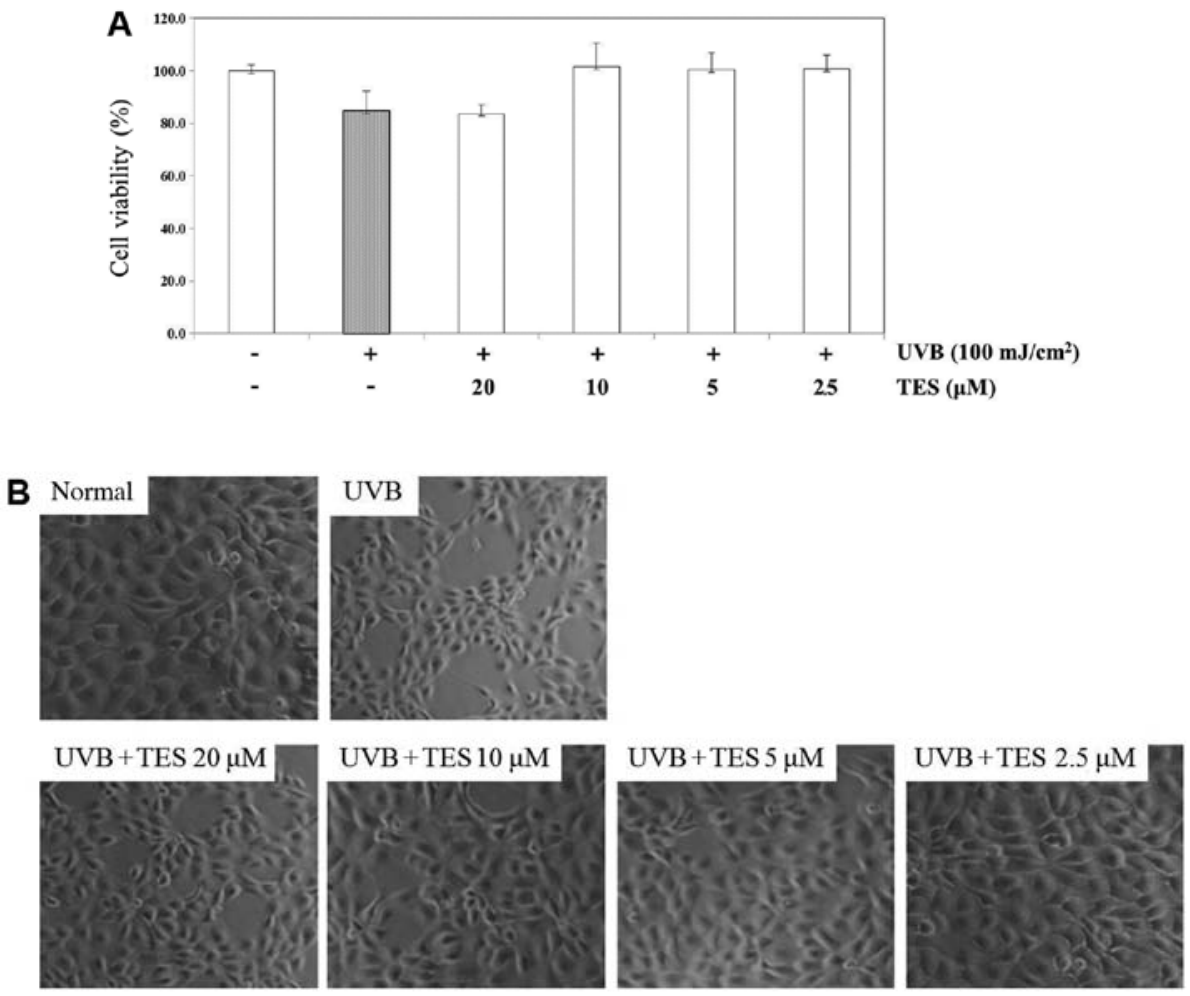

Figure 3. Effect of tectroside (TES) on cell viability and morphological alterations in HaCaT cells. (A) Cell viability was evaluated with the MTS assay. Data represent the means $\pm \mathrm{SE}$ of duplicate determinations from three separate experiments. (B) For morphological studies, cells were treated with TES (2.5, 5, 10 and $20 \mu \mathrm{M})$ for $24 \mathrm{~h}$ and then stimulated with UVB $\left(100 \mathrm{~mJ} / \mathrm{cm}^{2}\right)$ for $24 \mathrm{~h}$. 


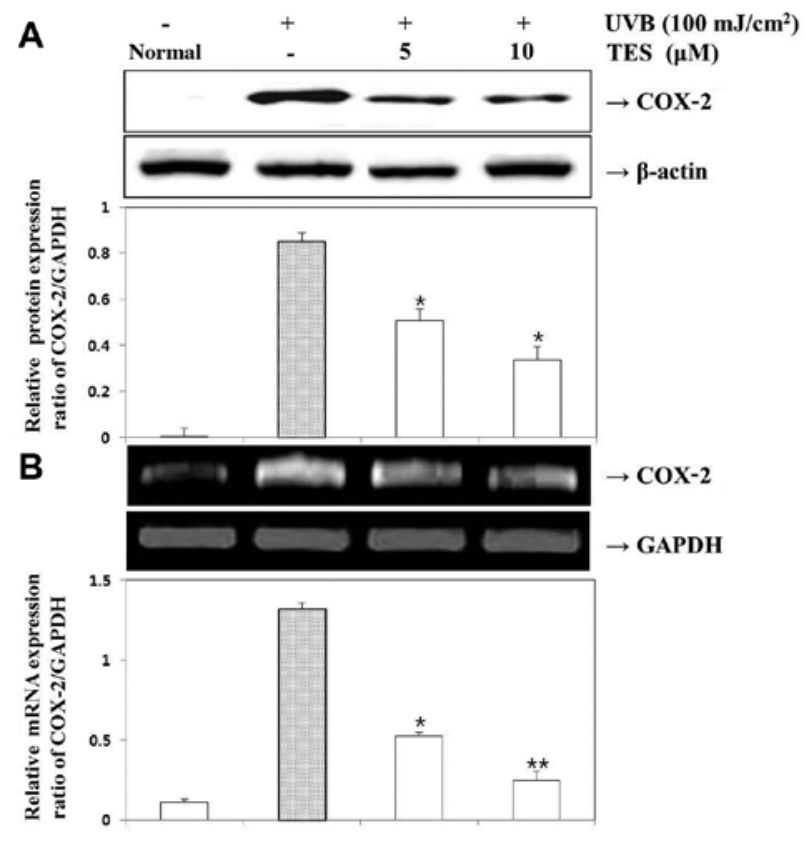

Figure 4. Effect of tectroside (TES) on UVB-induced COX-2 protein and mRNA expression in $\mathrm{HaCaT}$ cells. $\mathrm{HaCaT}$ cells were pretreated with the indicated concentrations of TES for $24 \mathrm{~h}$ before being irradiated with UVB $\left(100 \mathrm{~mJ} / \mathrm{cm}^{2}\right)$ for $24 \mathrm{~h}$. Equal amounts of protein $(20 \mu \mathrm{g})$ were separated by sodium dodecyl sulfate-polyacrylamide gel electrophoresis and immunoblotted with COX-2 antibodies. Equal protein loading was verified using $\beta$-actin. (A) COX-2 mRNAs were assessed by RT-PCR in HaCaT cells. Cells were pretreated with the indicated concentrations of TES for $24 \mathrm{~h}$ before being incubated with UVB $\left(100 \mathrm{~mJ} / \mathrm{cm}^{2}\right)$ for $24 \mathrm{~h}$. $\beta$-actin mRNA was assayed in parallel to confirm the equivalency of the cDNA preparations. (B) The experiment was repeated three times, and similar results were obtained. ${ }^{*} \mathrm{P}<0.05,{ }^{* *} \mathrm{P}<0.005$, when compared to the UVB-treated group. Significant differences between treated groups were determined using the Student's t-test. Values shown are the means $\pm \mathrm{SE}$ of duplicate determinations from three separate experiments.

Effect of TES on UVB-induced COX-2 mRNA expression. We next examined the effects of TES on COX-2 expression in UVB-irradiated HaCaT cells. The expression levels of COX-2 protein and COX-2 mRNA were measured in $\mathrm{HaCaT}$ cells exposed to UVB $\left(100 \mathrm{~mJ} / \mathrm{cm}^{2}\right)$ for $24 \mathrm{~h}$. TES effectively suppressed UVB-induced COX-2 expression. UVB $\left(100 \mathrm{~mJ} / \mathrm{cm}^{2}\right)$ also increased COX-2 mRNA expression, which was inhibited in the presence of TES (Fig. 4). Hence, TES suppressed the expression of genes that are implicated in the pathogenesis of inflammatory responses.

Effect of TES on IL-6 and IL-8 production in UVB-irradiated cells. Since TES inhibited the production of pro-inflammatory mediators in $\mathrm{HaCaT}$ cells, we further investigated its effects on UVB-induced IL- 6 and IL-8 production by performing ELISA and RT-PCR. We found that, depending on its concentration, TES inhibited UVB-stimulated IL-6 (Fig. 5) and IL-8 (Fig. 6) expression at both the protein and mRNA levels.

Effect of TES on the phosphorylation of MAPKs in UVB-induced HaCaT cells. MAPKs are essential for UVB-induced inflammation in HaCaT cells; therefore, we evaluated the effects of TES on the activation of MAPKs in these cells. TES markedly inhibited the phosphorylation of JNK1/2 and ERK1/2 MAPK; these results indicate that MAPK phosphorylation was inhibited by TES pretreatment (Fig. 7).
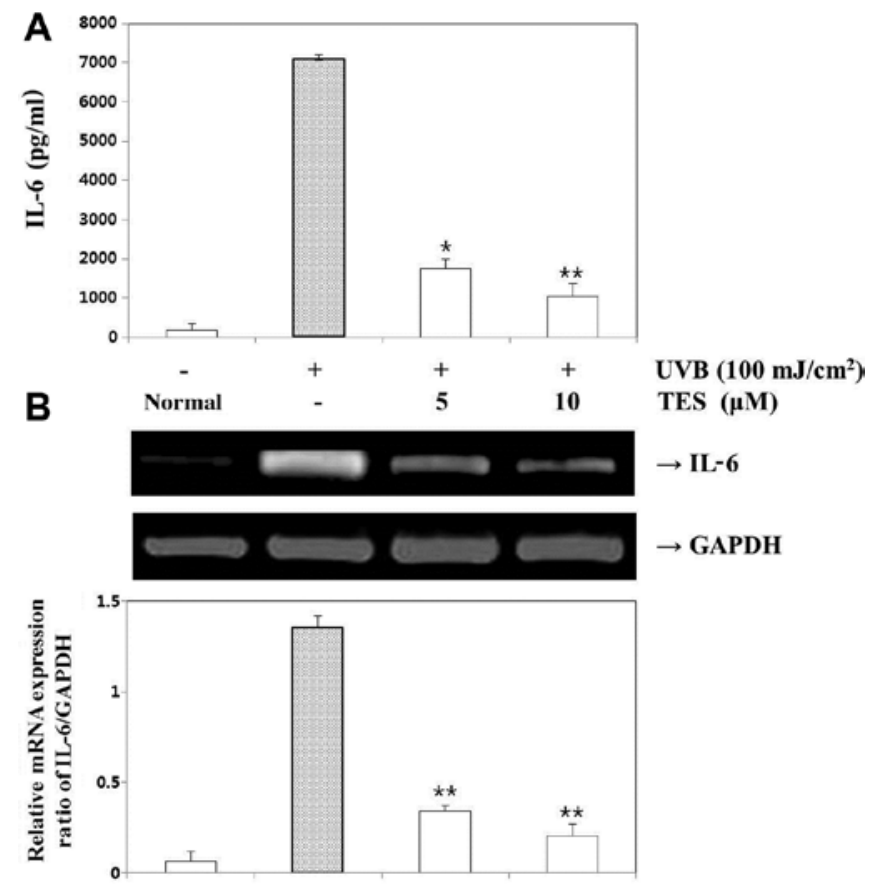

Figure 5. Effect of tectroside (TES) on UVB-induced IL-6 production. HaCaT cells were pretreated with the indicated concentrations of TES for $24 \mathrm{~h}$ before being irradiated with UVB $\left(100 \mathrm{~mJ} / \mathrm{cm}^{2}\right)$ for $24 \mathrm{~h}$. The production of IL- 6 was measured by ELISA. Cells were pretreated with the indicated concentrations of TES for $24 \mathrm{~h}$ before being irradiated with UVB $\left(100 \mathrm{~mJ} / \mathrm{cm}^{2}\right)$ for $24 \mathrm{~h}$. (A) Effect of TES on UVB-induced IL-6 mRNA expression. IL-6 mRNA was assessed by RT-PCR in HaCaT cells. Cells were pretreated with the indicated concentrations of TES for $24 \mathrm{~h}$ before being irradiated with UVB $\left(100 \mathrm{~mJ} / \mathrm{cm}^{2}\right)$ for $2 \mathrm{~h}$. $\beta$-actin mRNA was assayed in parallel to confirm the equivalency of the cDNA preparations. (B) Data are the means \pm SE values of duplicate determinations from three separate experiments. ${ }^{*} \mathrm{P}<0.05 ;{ }^{* *} \mathrm{P}<0.005$.

\section{Discussion}

I. dentata is a perennial medicinal herb indigenous to Korea. It was reported that intraperitoneal administration of the herb extract resulted in decreased blood glucose in alloxan diabetic mice (25) and prevented neurodegenerative diseases $(19,26)$. Young I. dentata sprouts are commonly used as a bitter appetizing in Korea. Chemical components including triterpenes, sesquiterpene glycosides, and flavonoids have been isolated from the genus Ixeris, which comprises approximately 20 species (27).

I. dentata is characterized by the presence of guaiane sesquiterpene lactones, which are chemosystematic markers. As a continuation of our effort to purify minor sesquiterpenes from I. dentata amino acid-sesquiterpene lactones, ixerisamine A and ixerisamine B were isolated together with 12 related sesquiterpene lactones (8-epi-desacylcynaropicrin glucoside; ixerisoside A; ixerisoside A 6'-O acetate; ixerin N; ixerin N 6'-O acetate; ixerin M; TES; 4,8-epiisolipidiol; 8 -epi-isolipidiol; $11 \beta \mathrm{H}$-11,13-dihydrointegrifolin; $8 \beta$-hydroxy4 $\beta, 15$-dihydrozaluzanin $\mathrm{C}$ and integrifolin) (24).

The isolation and structure determination of compounds, as well as the inhibitory effects of isolated sesquiterpenes on the proliferation of 4 cultured human tumor cell lines: MES-SA (human uterine carcinoma cell line), MES-SA/DX5 (multidrug-resistant subline of MES-SA), HCT-15 (human 


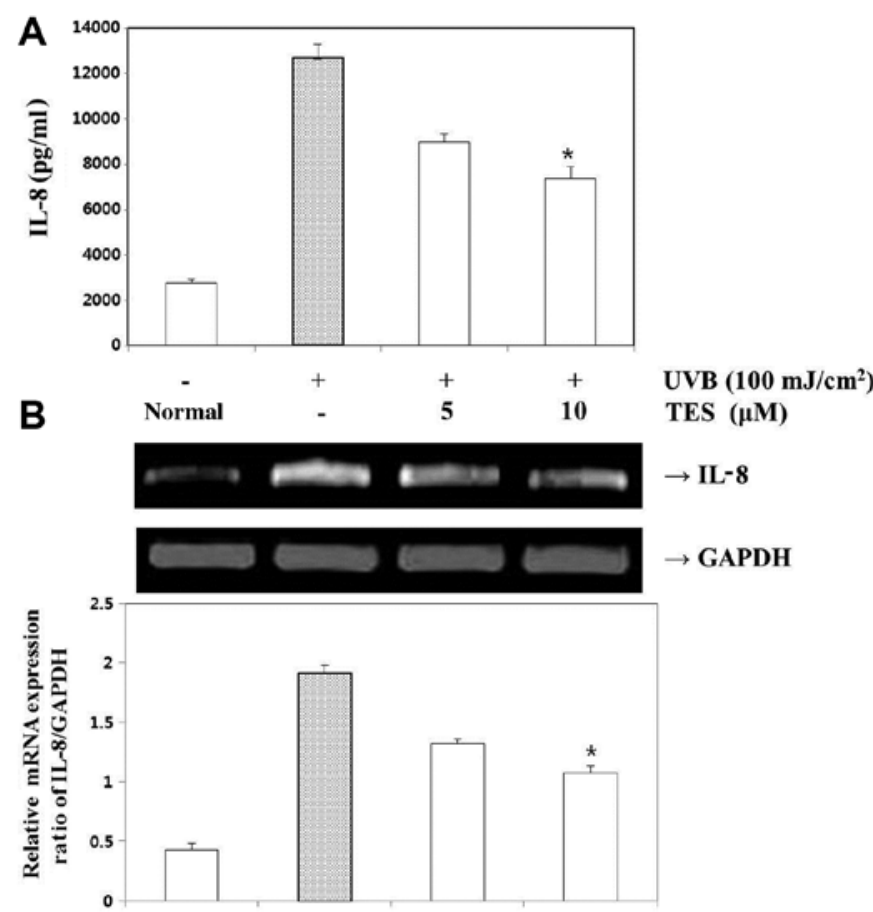

Figure 6. Effect of tectroside (TES) on UVB-induced IL-8 production. $\mathrm{HaCaT}$ cells were pretreated with the indicated concentrations of TES for $24 \mathrm{~h}$ before being irradiated with UVB $\left(100 \mathrm{~mJ} / \mathrm{cm}^{2}\right)$ for $24 \mathrm{~h}$. The production of IL-8 was measured by ELISA. Cells were pretreated with the indicated concentrations of TES for $24 \mathrm{~h}$ before being incubated with UVB $\left(100 \mathrm{~mJ} / \mathrm{cm}^{2}\right)$ for $24 \mathrm{~h}$. (A) Effect of TES on UVB-induced IL-8 mRNA expression. IL-8 mRNA was assessed by RT-PCR in HaCaT cells. Cells were pretreated with the indicated concentrations of TES for $24 \mathrm{~h}$ before being irradiated with UVB $\left(100 \mathrm{~mJ} / \mathrm{cm}^{2}\right)$ for $2 \mathrm{~h}$. $\beta$-actin mRNA was assayed in parallel to confirm the equivalency of the cDNA preparations. (B) Data are the means \pm SE values of duplicate determinations from three separate experiments. ${ }^{*} \mathrm{P}<0.05$.

colorectal adenocarcinoma cell line), and HCT-15/CL02 (multidrug-resistant subline of HCT-15) were evaluated (24).

UVB irradiation induces skin damage and inflammation by causing the secretion of various cytokines, which are immune regulators produced by cells. To prevent the initiation of skin inflammation, keratinocytes that have been irreversibly damaged by UVB must be removed through apoptosis. UVB crosses the epidermis and reaches the upper dermis. Compared with UVA, it is more active in terms of causing cutaneous carcinogenesis and alterations of the cell-cyclecontrol signaling pathways (5).

Keratinocytes are the major target of UVB and play a central role in inflammatory and immune modulatory changes observed after UV exposure, at least partly through the UV-induced release of cytokines (IL-1, IL-6, IL-8, IL-10, GM-CSF and TNF- $\alpha$ ) (28) and cyclooxygenase products (PGE2) (29).

Inappropriate expression and/or activity of COX-2, a rate-limiting enzyme involved in the biosynthesis of prostaglandins, has been implicated in UVB-induced skin carcinogenesis (30). MAPKs are a family of proline-directed Ser/Thr kinases comprising ERK, JNK and p38 MAPK. Recent studies have shown that activation of ERK, JNK and p38 MAPK is strongly correlated with acute inflammation and development of skin cancer through increased expression of COX-2 (31-33).
A
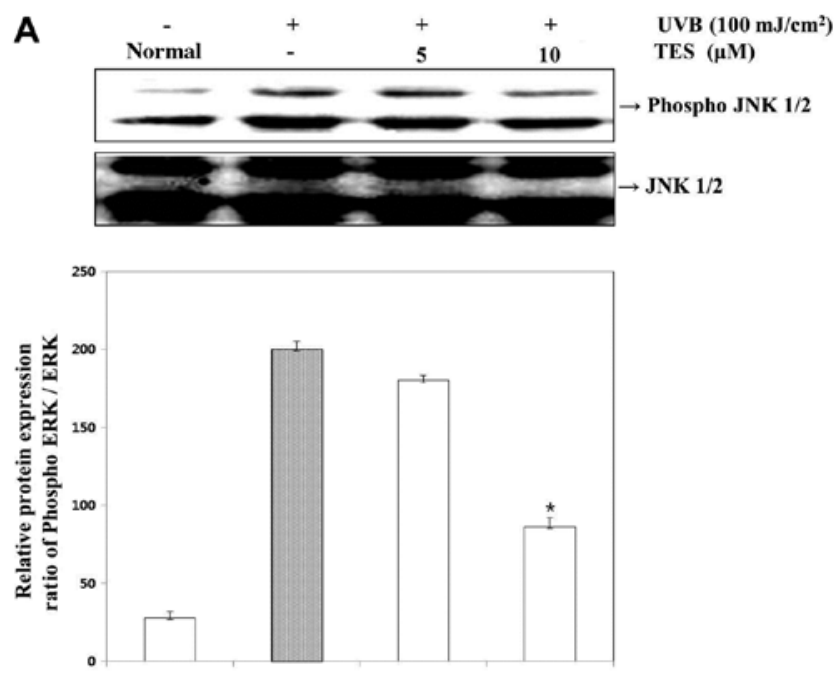

B
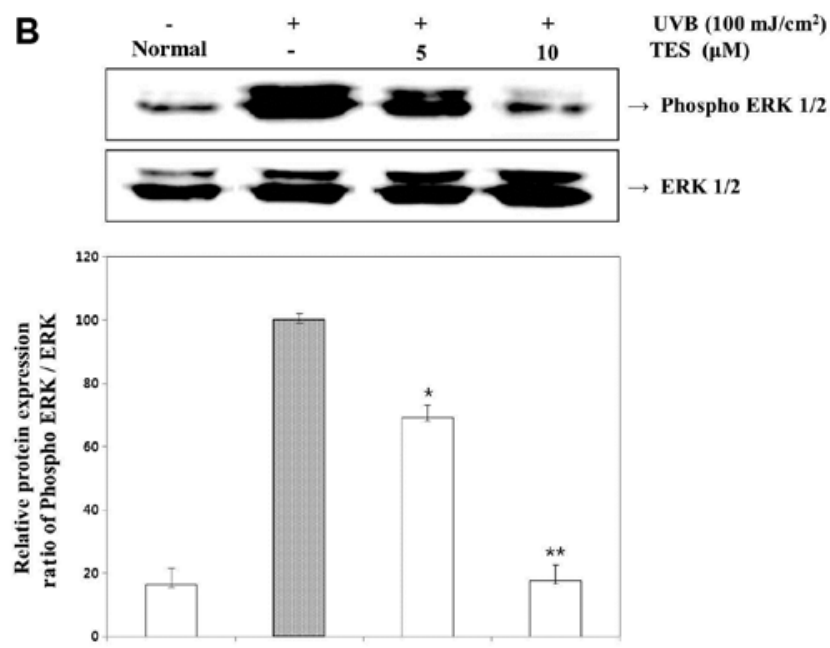

Figure 7. Effect of tectroside (TES) on the phosphorylation ( $\mathrm{P}^{-}$) of MAPKs in UVB-stimulated HaCaT cells. HaCaT cells were treated with the indicated concentrations of TES for $24 \mathrm{~h}$ before being irradiated with UVB $\left(100 \mathrm{~mJ} / \mathrm{cm}^{2}\right)$ for (A) $30 \mathrm{~min}$ and (B) $1 \mathrm{~h}$. Whole-cell lysates were analyzed by western blot analysis. The experiment was repeated three times, and similar results were obtained. ${ }^{*} \mathrm{P}<0.05 ;{ }^{* *} \mathrm{P}<0.005$

In the present study, TES was isolated from I. dentata. We examined the effect of TES on UVB-induced pro-inflammatory cytokine production in $\mathrm{HaCaT}$ cells by evaluating cells that were stimulated with UVB in the presence or absence of TES. Pro-inflammatory cytokine production was measured by ELISA and RT-PCR, and the activation of MAPKs was determined by western blot analysis.

In particular, we investigated whether TES inhibits the UVB-induced production of IL- 6 and IL- 8 by inhibiting the expression of MAPK and COX-2 at the protein and mRNA levels. We found that the inhibitory effects of TES on the production of inflammatory mediators were accompanied by concentration-dependent decreases in the protein and mRNA expression levels of IL-6, IL-8 and COX-2. These data demonstrate that IL-6, IL-8 and COX-2 expression in HaCaT cells is suppressed by TES; UVB-induced phosphorylation of JNK1/2 and ERK1/2 in HaCaT cells. Therefore, it is likely that TES acts as an antiphotoinflammatory agent by mainly inhibiting COX-2 expression in vivo. 
Inhibition of COX-2 expression has been shown to be an important anti-inflammatory mechanism of some compounds, including epigallocatechin gallate (34), resveratrol (35) and curcumin (36) similar to TES. Furthermore, these effects are mediated by the inhibition of COX-2 expression and JNK1/2 and ERK1/2 phosphorylation. In practice, the whole I. dentata plant, a typical Oriental herb, has been used for the treatment of indigestion, pneumonia, diabetes, hepatitis, contusions and tumors (16). It has also been used in Korean folk medicine for the treatment of inflammatory diseases; therefore, this represents a potent anti-inflammatory effect of TES accomplished by blocking inflammatory mediators. Our data suggest that TES represents a new source of potential drugs for the treatment of inflammatory diseases.

In conclusion, we evaluated the effect of TES on skin inflammation in vitro and found that TES has potential to attenuate UVB-induced skin inflammation by suppressing MAPK activation. Our findings provide new insight into the application of TES as well as its nutraceutical value. Further studies on TES are required to confirm its medicinal use.

\section{Acknowledgements}

This study was supported by Wonkwang University in 2011.

\section{References}

1. Murphy GF (ed): Structure, function and reaction patterns, In: Dermatopathology. W.B. Saunders, Philadelphia, PA, p25, 1995.

2. Yager J: The skin as an immune organ. In: Advances in Veterinary Dermatology. Ihrke PJ, Mason IS and White SD (eds). Pergamon Press, Oxford, p31, 1993.

3. de Gruijl FR, Sterenborg HJ, Forbes PD, Davies RE, Cole C, Kelfkens G, van Weelden H, Slaper H and van der Leun JC: Wavelength dependence of skin cancer induction by ultraviolet irradiation of albino hairless mice. Cancer Res 53: 53-60, 1993.

4. van der Leun J and de Gruijl F: Influence of ozone depletion on human and animal health. In: UV-B Radiation and Ozone Depletion: Effects on Humans, Animals, Plants, Microorganisms and Materials. Tevini M (ed). Lewis Publishers, Boca Raton, FL, pp95-123, 1993.

5. Rosette C and Karin M: Ultraviolet light and osmotic stress: activation of the JNK cascade through multiple growth factor and cytokine receptors. Science 274: 1194-1197, 1996.

6. Afaq F, Adhami VM and Mukhtar H: Photochemoprevention of ultraviolet B signaling and photocarcinogenesis. Mutat Res 571: 153-173, 2005.

7. Yaar $\mathrm{M}$ and Gilchrest BA: Photoageing: mechanism, prevention and therapy. Br J Dermatol 157: 874-887, 2007.

8. Malorni W, Donelli G, Straface E, Santini MT, Paradisi S and Giacomoni PU: Both UVA and UVB induce cytoskeletondependent surface blebbing in epidermoid cells. J Photochem Photobiol B 26: 265-270, 1994.

9. Zamansky GB, Perrino BA and Chou IN: Disruption of cytoplasmic microtubules by ultraviolet radiation. Exp Cell Res 195 269-273, 1991.

10. Zamansky GB and Chou IN: Disruption of keratin intermediate filaments by ultraviolet radiation in cultured human keratinocytes. Photochem Photobiol 52: 903-906, 1990.

11. Zamansky GB and Chou IN: Environmental wavelengths of ultraviolet light induce cytoskeletal damage. J Invest Dermatol 89: 603-606, 1987.

12. Moll I, Bohnert E, Treib U and Jung EG: Effects of ultraviolet B radiation on cytoskeletal and adhesion molecules in human epidermis. Photodermatol Photoimmunol Photomed 10: 26-32, 1994

13. Godar DE: Preprogrammed and programmed cell death mechanisms of apoptosis: UV-induced immediate and delayed apoptosis. Photochem Photobiol 63: 825-830, 1996.

14. Shindo $Y$ and Hashimoto T: Ultraviolet B-induced cell death in four cutaneous cell lines exhibiting different enzymatic antioxidant defences: involvement of apoptosis. J Dermatol Sci 17: $140-150,1998$
15. Kim SH: Inhibitory effects of Ixeris dentata on the mutagenicity of aflatoxin B1, N-methyl-N'-nitro-N-nitrosoguanidine and the growth of MG-63 human osteosarcoma cells. J Korean Soc Food Sci Nutr 24: 305-312, 1995

16. Kim M and Lee M: Volatile flavor components of Ixeris dentata and Amaranthus mangostanus. Han'guk Nonghwa Hakhoe chi 31: 394-399, 1988 (In Korean).

17. Lee E: Effects of Ixeris dentata ext. on lowering lipid and antioxidation. Korean J Plant Res 24: 55-60, 2011 (In Korean).

18. Park EK, Sung JH, Trinh HT, Bae EA, Yun HK, Hong SS and Kim DH: Lactic acid bacterial fermentation increases the antiallergic effects of Ixeris dentata. J Microbiol Biotechnol 18: 308-313, 2008.

19. Chung HS: Inhibition of monamine oxidase by a flavone and its glycoside from Ixeris dentata Nakai. Nutraceut Food 8: 141-144, 2003.

20. Chung HS, Jeong HJ, Han MJ, Park ST, Seong KK, Baek SH, Jeong DM, Kim MJ and Kim HM: Nitric oxide and tumor necrosis factor-alpha production by Ixeris dentata in mouse peritoneal macrophages. J Ethnopharmacol 82: 217-222, 2002.

21. Kim SB, Kang OH, Keum JH, Mun SH, An HJ, Jung HJ, Hong SH, Jeong DM, Kweon KT and Kwon DY: Anti-inflammatory effect of Ixeris dentata on ultraviolet B-induced $\mathrm{HaCaT}$ keratinocytes. Nat Prod Sci 18: 60-66, 2012 (In Korean).

22. Kim MJ, Kim JS, Jeong DM, Han SS and Yu CY: Effect of antioxidant, antimutagenicity and anticancer of root extract from Ixeris dentata Nakai. Korean J Med Crop Sci 10: 222-229, 2002.

23. Kim JH, Lim HS, Ha H, Seo CS and Shin HK: Inulae flos and its compounds inhibit TNF- $\alpha$ - and IFN- $\gamma$-induced chemokine production in HaCaT human keratinocytes. Evid Based Complement Alternat Med 2012: 280351, 2012.

24. Cha MR, Choi YH, Choi CW, Yoo DS, Kim YS, Choi SU, Kim YH and Ryu SY: New guaiane sesquiterpene lactones from Ixeris dentata. Planta Med 77: 380-382, 2011.

25. Choi JS, Young HS and Kim BW: Hypoglycemic and hypolipemic effects of Ixeris dentata in diabetic rats. Arch Pharm Res 13: 269-273, 1990.

26. Oh SH, Sung TH and Kim MR: Ixeris dentata extract maintains glutathione concentrations in mouse brain tissue under oxidative stress induced by kainic acid. J Med Food 6: 353-358, 2003.

27. Zidorn C: Sesquiterpene lactones and their precursors as chemosystematic markers in the tribe Cichorieae of the Asteraceae. Phytochemistry 69: 2270-2296, 2008.

28. Takashima A and Bergstresser PR: Impact of UVB radiation on the epidermal cytokine network. Photochem Photobiol 63: 397-400, 1996.

29. Grewe M, Trefzer U, Ballhorn A, Gyufko K, Henninger $\mathrm{H}$ and Krutmann J: Analysis of the mechanism of ultraviolet (UV) B radiation-induced prostaglandin E2 synthesis by human epidermoid carcinoma cells. J Invest Dermatol 101: 528-531, 1993.

30. An KP, Athar M, Tang X, Katiyar SK, Russo J, Beech J, Aszterbaum M, Kopelovich L, Epstein EH Jr, Mukhtar H and Bickers DR: Cyclooxygenase-2 expression in murine and human nonmelanoma skin cancers: implications for therapeutic approaches. Photochem Photobiol 76: 73-80, 2002.

31. Chen W, Tang Q, Gonzales MS and Bowden GT: Role of p38 MAP kinases and ERK in mediating ultraviolet-B induced cyclooxygenase-2 gene expression in human keratinocytes. Oncogene 20: 3921-3926, 2001.

32. Lin SK, Kok SH, Yeh FTC, Kuo MYP, Lin CC, Wang CC, Goldring SR and Hong CY: MEK/ERK and signal transducer and activator of transcription signaling pathways modulate oncostatin M-stimulated CCL2 expression in human osteoblasts through a common transcription factor. Arthritis Rheum 50: 785-793, 2004.

33. Mahns A, Wolber R, Stäb F, Klotz LO and Sies H: Contribution of UVB and UVA to UV-dependent stimulation of cyclooxygenase-2 expression in artificial epidermis. Photochem Photobiol Sci 3: 257-262, 2003.

34. Vayalil PK, Elmets CA and Katiyar SK: Treatment of green tea polyphenols in hydrophilic cream prevents UVB-induced oxidation of lipids and proteins, depletion of antioxidant enzymes and phosphorylation of MAPK proteins in SKH-1 hairless mouse skin. Carcinogenesis 24: 927-936, 2003.

35. Afaq F, Adhami VM and Ahmad N: Prevention of short-term ultraviolet $\mathrm{B}$ radiation-mediated damages by resveratrol in SKH-1 hairless mice. Toxicol Appl Pharmacol 186: 28-37, 2003.

36. Cho JW, Lee KS and Kim CW: Curcumin attenuates the expression of IL-1 $\beta$, IL-6, and TNF- $\alpha$ as well as cyclin $E$ in TNF- $\alpha$-treated $\mathrm{HaCaT}$ cells; NF- $\kappa \mathrm{B}$ and MAPKs as potential upstream targets. Int J Mol Med 19: 469-474, 2007. 